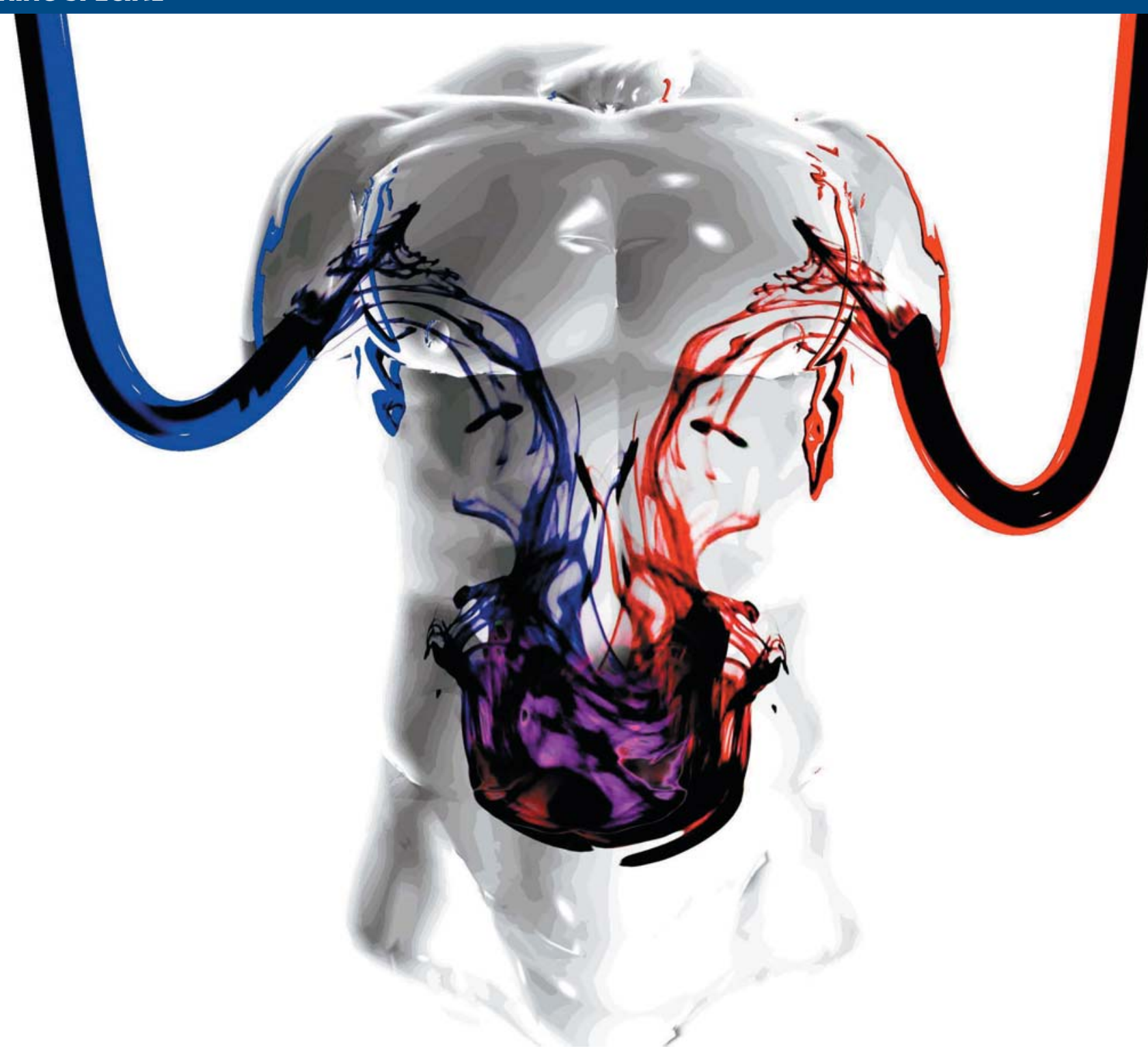

\title{
Do we even need eggs?
}

\section{それでも卵が必要か?}

Nature Vol.439 (655-657)/9 February 2006

拒絶されれば誰だってつらい。だが、臟器 移植手術を受けた者にとってそれは、死を 宣告されるに等しいことにもなる。患者の 免疫系は、移植された臓器 (移植片) を「自 己」ではなく「異物」としてみなすため、 患者は、時に重い副作用が現れる免疫抑 制剂を手放すことができない。治療目的 のクローン作製は、その推進者によると、
個々の患者に完全に適合した細胞や組織 を作り出せることから、この免疫の問題の 解決につながるのだという。この手法で は、患者のDNAを核に導入した卵細胞か ら幹細胞を作製し、さらにはそこからスペ アパーツとなる組織が作り出されるよう 誘導する。しかし治療目的のクローン作製 は現在、主にヒトの卵子 (卵ともいう) が
十分に入手できないという理由から現実 的でないと考えられている。

このため、研究者たちは戦略を変更し、 免疫系を説得して外来組織に対して寛容 性を示すようにさせることができないか を考え始めている。「この研究領域は激動 しています。10 年もたてば、特別な場合 を除いてクローン作製は必要なくなって 
いるかもしれません」と、シェフィール ド大学（英国）にある幹細胞生物学セン ターの Harry Moore は語る。

組織移植の成功率を高めるためにはさ まざまな方法がある。その 1 つは、一般 的な幹細胞、細胞系列、組織を作製した 後に、これらを拒絶することなく受け入 れるよう免疫系を誘導することだ。例え ば、1 型糖尿病などの治療に用いるインス リン産生細胞の治療用移植物などが考え られる。このアイデアの実現に取り組む 研究者たちは、実際に臨床現場で実施さ れるまでにはまだ数年、あるいは数十年 かかることを認めている。このため、よ り現実的な取り組みも進んでいる。免疫 系に対して移植組織を完全に受け入れさ せようとするのではなく、強力な免疫抑 制剂に依存する必要性を大きく減らすこ とができる程度にまで、免疫系の「寛容性」 を高めようというのだ。

ただ当面は、臓器移植手術を受けた多 くの人々に、シクロスポリンやステロイ ドといった、免疫系全体に作用する薬剂 を生涯にわたって投与する必要がある。 こうした薬剤は、移植臓器の寿命を数年 は延ばすものの、やがては起きうる拒絶 反応を避けられないことも多く、こうな ると患者は、感染症やがん、腎不全のリ スクにさらされることになる。

\section{薬物問題}

臓器移植を受けた少数の患者を対象とし た複数の研究から、免疫系を操作するこ とで薬剤療法への依存度を低減できるこ とを明らかにした医療チームがある。たと えば、アデンブルーク病院（英国、ケンブ リッジ) の Chris Watson と Roy Calne は、 Campath-1（アレムツズマブ）とよばれる 抗体を臟器移植時に患者に投与することを 試みている 1 。この抗体は、重要な免疫細 胞の主要ファミリーであるリンパ球を体內 から除去する。

さらにこれらの患者に対し、臓器移植 後に投与する免疫抑制剂の量を通常より も減らし、ステロイドは使用しなかっ た。 5 年間の試験中、これらの患者の移
植片は従来の治療法を受けた患者の臓器 と同程度に生存した。Campath-1 を開 発したオックスフォード大学 (英国) の Herman Waldmann は、この治療法は まだ広く採用されるにはいたっていない という。しかし、試験で得られた結果は、 免疫抑制剂の使用を極力抑えられること を示すものであるとも話す。

こうした抗体治療の作用メカニズムに ついて、研究者の間で見解が一致してい るわけではない。一部の研究者は、免疫 系の攻撃を回避することにより、免疫系 が何らかの形で移植片に寛容となるよう 「学習する」時間を得ているのではないか と推測している。当面の目標は、こうし た寛容が起きるしくみについて理解を深 めることにある。理解が進めば、さらに 緻密な治療法を組み立てることができる だろう。だが、結局あらゆる種類のリン パ球の作用をブロックしてしまうような 抗体は、まだ未熟な治療法であるにすぎ ないとWaldmann はいう。

免疫系は、「自己」と「非自己」のタン パク質を区別する。この過程には、T細 胞とよばれる 1 群のリンパ球が関与する。 個々の丁細胞の表面には、特定のタンパ ク質断片（ペプチド）に適合するようそ れぞれが固有の形状をした受容体が存在 する。そして丁細胞とはまた別の免疫系 細胞が体内をパトロールし、タンパク質 や抗原を拾い上げ、その断片を丁細胞に 提示する。それらの断片が特定の T細胞 受容体に適合すると、鍵穴にぴったりと はまる鍵のように作用し、条件しだいで はT細胞を活性状態へと切り替える。こ のような T細胞は後に、対象タンパク質 に対する免疫応答を調整する。

丁細胞が自己タンパク質に反応して活性 化してしまうとたいへんなことになるの はいうまでもない。このため、心臓のす ぐ上に位置する胸腺で成熟する新規丁細 胞がさまざまなタンパク質断片に遭遇す る際、自己抗原を特異的に認識するよう な丁細胞は死滅するしくみになっている。 すなわち、自己タンパク質に反応する $丁$ 細胞は「除去」されてしまうわけだ。「中
枢性トレランス」として知られるこの編 集過程が、通常は我々を自己免疫疾患の 発症から守ってくれている。この過程は 主に小児期および若年期に進行し、成熟 するにつれて胸腺は縮小してゆく。

そして、この中枢性トレランスが生じてい る間、少なくとも生まれたばかりのマウスで は、外来の細胞についても「自己」として 認識するようにだますことができることが わかっている ${ }^{2}$ 。その手順は以下のようなも のだ。若齢個体に骨髄細胞を注射する。こ の骨髄細胞は、下細胞の前駆体と、丁細胞 に対してタンパク質断片を提示する際に重 要な役割を果たすリンパ細胞の樹状細胞で ある。体外の骨髄に由来する樹状細胞が胸 腺に移動し、そのタンパク質断片が胸腺で 成熟中の T細胞に提示されると、そのタン パク質断片は自己のものとみなされる。そ してそのような認識をした T細胞は死滅す る。結果的にこの動物個体は後に、骨髄細 胞を提供したのと同じドナーからの皮膚移 植片を受け入れることができるようになる。

\section{命令系統に注目}

しかし、このような取り組みが成人を対象 とした治療に適さないのは明らかだ。成 人の場合、胸腺で産生される新規 $T$ 細胞 は極めて少ないからである。このため研究 者たちは、成熟した免疫系を操作して、あ る種の人工的な中枢性トレランスを誘導 する可能性を探っている。動物実験では、 宿主の骨髄を部分的に不活性化し、新し いドナー骨髄を注入する試みが行われた。 外来の骨髄細胞の存在は、「混合キメラ現 象」として知られる状態を作り出す ${ }^{3}$ 。こ の状態では、宿主由来の抗原、またはド ナ一由来の抗原のいずれかと反応する 細胞が死滅し、個体は同じドナー由来のほ かの組織を受け入れるようになる。

Megan Sykes と David Sachsのグルー プは、このキメラ現象を利用して、骨髄と 腎臓の移植組織を受け入れるように免疫 系を促す試みを、少人数の成人患者を対象 に行った。まず研究チームは、宿主（患者） のリンパ球を除去する薬剤を患者に投与 し、次に新しい組織の移植を行った。当初、 
患者の血液にはキメラ現象が認められた。 つまり、ドナー組織由来であることの特徵 を示す多様な血液細胞の存在が確認され た。もしこの知見が動物実験の結果と一 致するものならば、ドナー組織に反応した T細胞は、あたかも自己を標的としたとし て除去されたことを示す。

しかし、これには謎が残った。移植片 そのものは数年間生き延びたものの、ド ナーの血液細胞がなぜか 12 週間ほど後か ら徐々に消失し始めたのだ。これは患者 がもはやキメラではないことを意味する。 つまり、必ずしもキメラ現象が、移植片 の生存についてのすべてを十分に説明で きるわけではなく、何かほかの要因も加 わることで拒絶が起きないようになって いるということが示された。これについ て Sykes は、腎臓の移植片そのものが、 宿主免疫系が移植片を受け入れる段階で 何らかの関与をしているに違いないと考 えている。このような寛容は、胸腺にお ける 丁細胞の中枢性除去と関係するので
はなく、移植組織の周囲である末梢部分 で生じているようだ。

Sykes が挙げる 1 つの可能性は、調節 性 $T$ 細胞として知られる、専門能力をもっ たT細胞集団の関与である。受け入れが 寛容された移植片の近くに潜んでいると ころが見つかることもあるこの調節性 $T$ 細胞は、多くの免疫学者の注目を集めつ つある。Waldmann は、調節性 T細胞が、 移植片の長期生存を維持するにあたって の重要な役割を果たしている可能性があ ると考えている。彼は、調節性 T細胞を 利用することでやがて、移植片に対する 免疫系の作用を抑える予防的治療を行え るのではないかと期待しており、「負のワ クチン接種」という言葉を作り出した。

\section{培養の妙技}

調節性 $丁$ 細胞は、周囲に存在するほかの 免疫細胞が活性化するのを制御したり、 その警戒に当たったりしているようだ。 調節性 $T$ 細胞がドナー抗原に対する活発

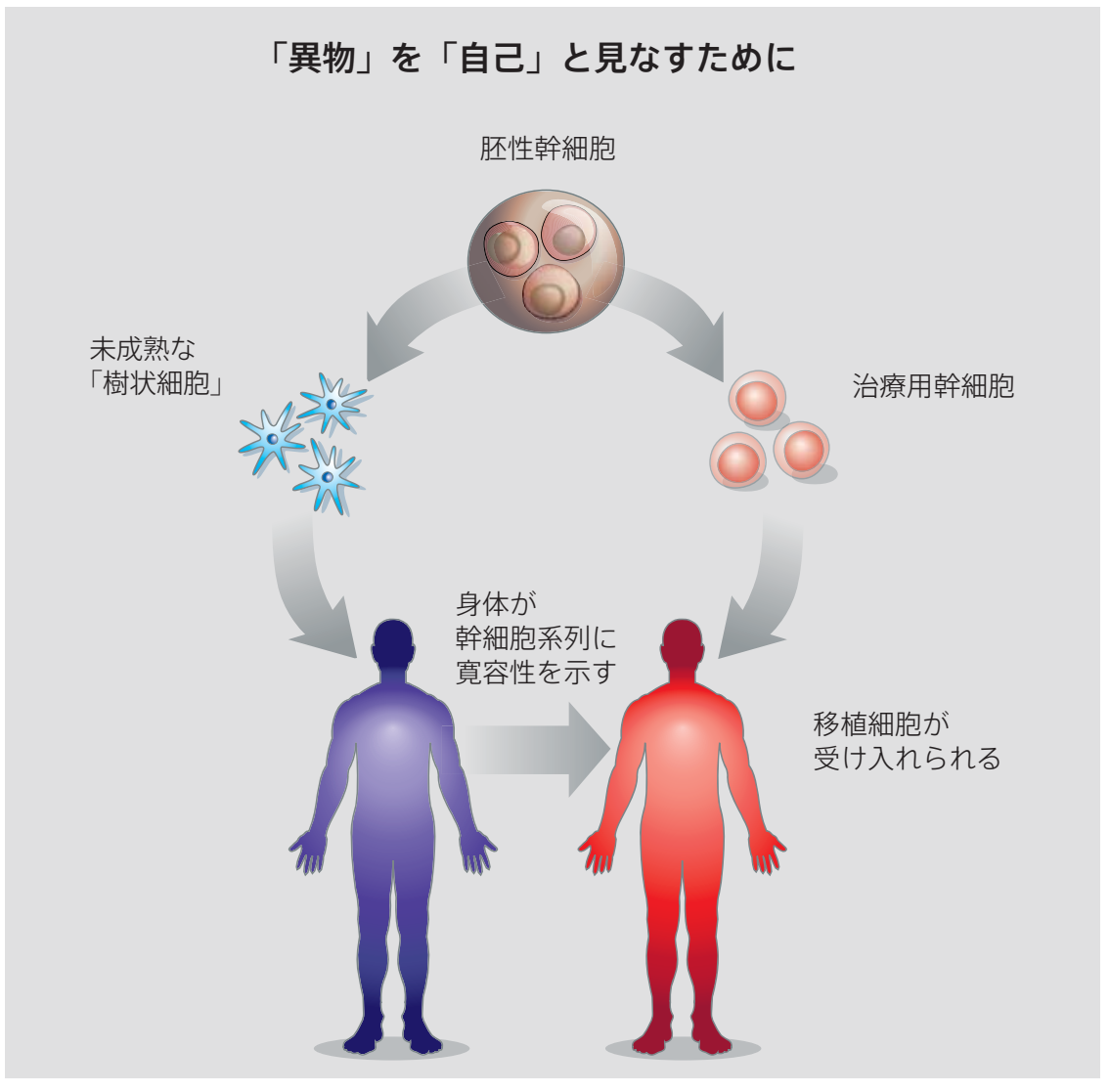

な免疫応答を抑制することにより移植片 の保護を促しているとするWaldmann の解釈には、樹状細胞の果たす役割が鍵 を握っていると思われる。

仮に丁細胞が、「免疫軍」を指揮する将 軍だとすれば、樹状細胞はさしずめ歩哨 や偵察に当たる。樹状細胞は皮膚や粘膜 をパトロールし、外来タンパク質を拾い 上げ、その断片を丁細胞の前に提示する。 樹状細胞はまた、こうしたタンパク質の行 く末を左右する調停者としても働き、丁細 胞がそれを攻撃するか寛容するかの決定 に影響を及ぼす ${ }^{4}$ 。

細菌由来の糖や、創傷部位周辺でのみ 放出される自己タンパク質などといった 炎症誘起性分子である「危険信号」の存 在下で樹状細胞が外来組織と遭遇すると、 細胞は速やかに成熟型へと姿を変える。 こうしてできた成熟型の樹状細胞は、丁細 胞に対して攻撃態勢に入るよう知らせる 信号を発する。ところが、前述のような 危険信号が存在しない場合には、樹状細 胞は未成熟な状態にとどまる。未成熟な 樹状細胞も外来タンパク質を丁細胞に提 示する能力をもってはいるが、一般的に は、抗原を特異的に認識する丁細胞を「退 役」へと導くことで、T細胞が抗原に激し く応答するのを妨げる。

Waldmann は、移植片の近傍における 樹状細胞と $丁$ 細胞の相互作用が、移植片 が受け入れられるかどうかに極めて重要な 役割を果たすと主張する。移植時には、局 所的な外傷によって移植組織に炎症が生 じるが、宿主免疫系によるリンパ球の急襲 はリンパ球除去薬を投与することで抑えら れる。Waldmann はこれで組織が治癒す るための時間稼ぎができると指摘する。組 織が治癒したら、そして感染症が発症しな ければ、移植片周囲の丁細胞に外来抗原 を提示する樹状細胞は、危険信号のない 条件下で作用するものと考えられる。結果 的に樹状細胞は、遭遇した T細胞をそれ ほど活性化させないはずだ。むしろ樹状細 胞は、丁細胞をまとめて「退役」へと導く か、もしくは調節性 $\mathrm{T}$ 細胞に変身するよう に促す。そうした調節性 丁細胞は、ほかの 
著作権等の理由により画像の掲載はできません。

樹状細胞は、組織移植片の寛容を促す役割を 担っているのかもしれない。

T細胞の警戒に当たり、さまざまな攻撃を 打ち払うことになる。Waldmann はPaul Fairchild たちと共に、幹細胞由来の移植 片に寛容性をもたせるためのツールとして 樹状細胞を利用できないか検討中だ。

5 年前、Fairchild の研究チームは、マ ウスの胚性幹細胞を培養血上で樹状細胞 へと分化させる方法の開発に取り組ん だ ${ }^{5}$ 。そして、樹状細胞の特徵が比較的長 期にわたって安定することを明らかにし た。樹状細胞は十分に分化し、発生過程 が逆転して幹細胞に戻るようなこともな かった。それらは「未成熟」な樹状細胞 の特徵をもち、丁細胞に寛容性をもたらす 可能性が極めて高い形態にあった。

Fairchild は、ヒトの樹状細胞について も同様の手順で培養すれば、移植片に寛
容性をもたらすように作用させることが できるだろうと推測している。樹状細胞 と、移植に必要な治療用の幹細胞（例え ば心笳細胞）の両方をもし同じ幹細胞か ら系列として培養できるなら、治療用細胞 が患者の体内で受け入れられるよう樹状 細胞を利用することも可能かもしれない 6 (左ページの図を参照)。

\section{時期尚早}

Fairchild たちはまだ、この仮説をマウス で詳しく検討するにはいたっていないが、 未発表の実験によれば、特定のタンパク質 を備えた樹状細胞を注入されたマウスは、 同じタンパク質をもつ皮膚移植片を受け 入れることができる可能性が示されてい る。Fairchild は、胚性幹細胞からヒトの 樹状細胞を培養する実験を始めている。

しかし、樹状細胞が成熟型へと姿を変え て T細胞を活性化してしまうリスクは残 る。このようなことになれば、樹状細胞 は移植片を保護するどころか、むしろ破 壊するほうに協力しかねない。Fairchild とWaldmannは、さまざまな化合物を 使って培養細胞を処理することで、細胞 を「寛容」状態に維持する方法を探って いる7 。しし Fairchild が重ねていうよ うに、実験はまだまだ初期の段階だ。

また、すべての研究者が、胚性幹細胞か ら分化させた細胞が移植治療に適している と信じているわけではない。マクマスター
大学 (カナダ、オンタリオ州) の免疫学研 究者Mick Bhatia は、たとえどれほど厳 密に制御された条件下であっても、未分 化の幹細胞が分化済みの幹細胞集団の中 に紛れ込む可能性はなくならないはずだと の懸念を示す。未分化の幹細胞には、ある 種のがんの増殖を引き起こす恐れもある。 Waldmann と Fairchild は、自分たちの 取り組みが実際に治療に用いられるまでに は、培養細胞系列中に含まれる可能性のあ る未分化細胞を同定する方法を開発しなけ ればならないという意見で一致している。

明日にでも寛容が可能となる、などとう そぶく研究者はいない。「しか重要なのは、 この研究分野を見込みのありそうなあらゆ る方向に展開することだ」とWaldmann は語る。心臓病などの変性疾患は増加の一 途をたどっているため、Fairchild を始めと する研究者は、自分たちの研究を推し進め ていく必要性を確信している。そして、「成 すべきことは山積みだが、やってやろうと いう気持ちだ」と話す。

Phyllida Brown は、英国エクセター州在住の サイエンスライター。

1. Watson, C. J. et al. Am. J. Transplant. 5, 1347-1353(2005)

2. Billingham, R. et al. Nature 172, 603-606 (1953).

3. Buhler, L. H. etal. Transplantation 74, 1405-1409 (2002).

4. Steinman, R. M. etal. Annu. Rev. Immunol. 21, 685 (2003)

5. Fairchild, P. J. et al. Curr. Biol. 10, 1515-1518 (2000).

6. Fairchild, P. J. et al. Trends Immunol. 25, 465-470 (2004)

7. Fairchild, P. J.etal. Intl. Immunopharmacol. 5, 13-21(2005).

\section{大きな期待}

世界中のたくさんの人々が、 体外の組織を何か月間もまっ たく問題なく受け入れている。 科学的なトリックはない。妊 娠がまさにそれだ。研究者た ちは、妊娠女性が胎児に対し て示す寛容性のしくみの解明 に取り組んでいる。理解が進 むことで流産の予防につなが る可能性もある。

こうした研究者グループの 1 つが、シェフィールド大学 (英国)
のHarry Moore率いる研究チー ムだ。彼らは、胎盤に含まれる 特殊な血管細胞の研究を進めて いる。この細胞は、母親の十細 胞が胎児を攻撃するのを防いで いるとみられる、HLA-G とよば れるタンパク質を分泌する。

最近、単球とよばれる免疫 細胞もまた HLA-G を産生する ことが報告された。興味深い ことにこの単球は、移植直後 の組織に浸潤する細胞である。
HLA-Gの発現量が増えると、 移植片が許容される確率は高 くなる。Mooreによればこれ は、HLA-Gが本来、一部の組 織移植片の保護を促す作用を もっているらしいことを示し ている。ただし、この作用が 起きる過程はまだわかってい ないとMoore は強調する。

研究グループは、この種の 血管細胞の研究によって、胚 が通常どのように着床するの
か、またなぜ一部の母親の免 疫系は胎児を拒絶するのかに ついて多くのことが明らかに なると期待している。そして 長期的には、心臓病の移植治 療用細胞の開発につながるか もしれないとMooreは語る。 この細胞を、そのほかの治療 用組織とあわせて使用するこ とで、移植を受ける患者がそ の両方に寛容性を示すことが 期待される。 